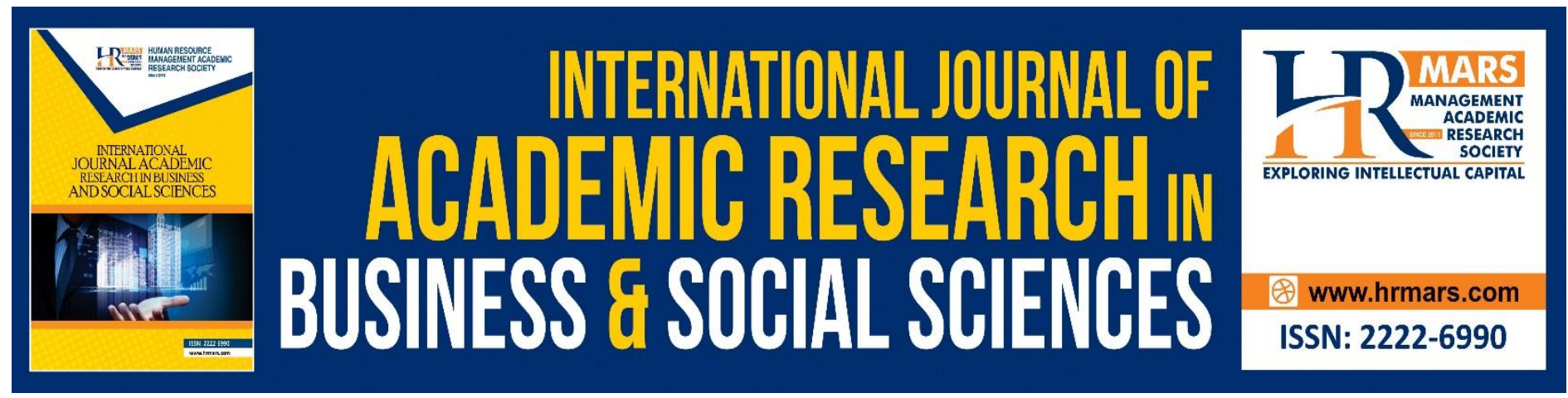

\title{
Market Structure and Efficiency of QISMUT Banking Sector
}

Noor-Shazreen Mortadza, Rossazana Ab-Rahim \& Alim Dee

To Link this Article: http://dx.doi.org/10.6007/IJARBSS/v9-i6/5958

DOI: $10.6007 /$ IJARBSS/v9-i6/5958

Received: 11 April 2019, Revised: 17 May 2019, Accepted: 09 June 2019

Published Online: 29 June 2019

In-Text Citation: (Mortadza, Ab-Rahim, \& Dee, 2019)

To Cite this Article: Mortadza, N.-S., Ab-Rahim, R., \& Dee, A. (2019). Market Structure and Efficiency of QISMUT Banking Sector. International Journal of Academic Research in Business and Social Sciences, 9(6), 383-392.

\section{Copyright: (C) 2019 The Author(s)}

Published by Human Resource Management Academic Research Society (www.hrmars.com)

This article is published under the Creative Commons Attribution (CC BY 4.0) license. Anyone may reproduce, distribute, translate and create derivative works of this article (for both commercial and non-commercial purposes), subject to full attribution to the original publication and authors. The full terms of this license may be seen at: http://creativecommons.org/licences/by/4.0/legalcode

Vol. 9, No. 6, 2019, Pg. 383 - 392

Full Terms \& Conditions of access and use can be found at http://hrmars.com/index.php/pages/detail/publication-ethics 


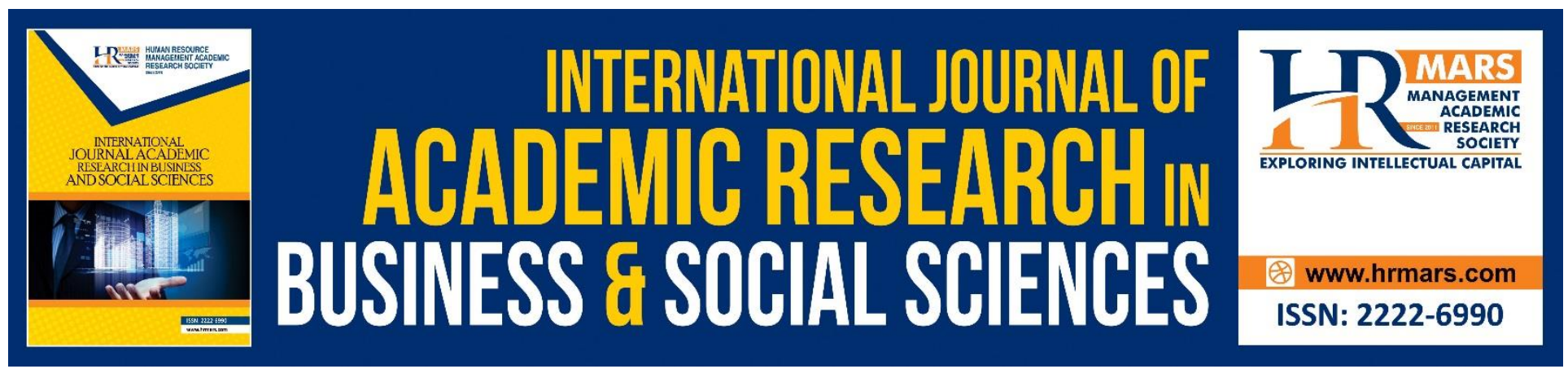

\title{
Market Structure and Efficiency of QISMUT Banking Sector
}

\author{
Noor-Shazreen Mortadza, Rossazana Ab-Rahim \& Alim Dee \\ Faculty of Economics and Business, Universiti Malaysia Sarawak, Sarawak.
}

\begin{abstract}
The aim of this study is to assess the market structure and efficiency of QISMUT (Qatar, Indonesia, Saudi Arabia, Malaysia, United Arab Emirates and Turkey) banking market over the study period of 2006 to 2016. Concentration ratio and Herfindahl-Hirshman Index are used to measure market structure while efficiency is measured using Data Envelopment Analysis (DEA). The results show conventional banks in QISMUT are more concentrated than its counterpart, the Islamic banks. However, Islamic banks are found to be more efficient than the conventional banks.
\end{abstract}

Keywords: Market Structure, Efficiency, QISMUT, Banking Market

\section{Introduction}

The presence of foreign banks in domestic market is one of the factors that affects the number of the banks in the industry. Mason (1939) mentioned that market structure affects the performance of the firms which is known as conduct in 'Structure-Conduct-Performance' paradigm. Increasing number of banks directly affects the market structure and competition in industry. This has been supported by Rajan and Zingales (2003) which mentioned that entry of foreign banks could trigger the competition. However, competition in financial industry also affects the stability of financial industry (Demirguc-Kunt \& Detragiache, 1998; Demirguc-Kunt, Levine \& Min, 1998).

On this note, Andries and Capraru (2012) mentioned competition affects the performance of the banks in terms of efficiency while Apergis and Polemis (2016) claimed efficiency of banks is triggered by the competition in context of European banking scenario. Schaeck and Cihak (2008) offered support to the former study that high competition would increase firms' profits. Casu and Girardone (2009) added inefficient banks are mostly acquired by the big banks to improve the efficiency in industry.

QISMUT Islamic banking market offers an interesting avenue to investigate the efficiency performance of the banks. QISMUT banking market consists of six countries namely Qatar, Indonesia, Saudi Arabia, Malaysia, United Arab Emirates (UAE) and Turkey. On this note, Islamic banking assets is dominated by QISMUT countries because these countries are known as the rapid growth market 
INTERNATIONAL JOURNAL OF ACADEMIC RESEARCH IN BUSINESS AND SOCIAL SCIENCES

Vol. 9, No. 6, June, 2019, E-ISSN: 2222-6990@ 2019 HRMARS

especially in Islamic banking sector globally (Ernst \& Young, 2016). In this respect, QISMUT Islamic banks contributes 80 percent (\%) of market shares higher than the conventional banks in QISMUT banking market. It is interesting to include conventional banks of QISMUT in this study because of most population are Muslim but some countries are dominated by conventional banks in terms of total assets. It is interesting to highlight past studies have tended to focus on regions such as Middle East and North Africa (MENA) region and Asian countries. Hence, this study aims to fill the gap in the previous studies whereby there is no study focus on QISMUT; this study also aims to compare the efficiency performance between Islamic and conventional banks in QISMUT banking sector.

Specifically, this study investigates the market structure and the main sources of efficiency performance and decomposes its sources, namely scale efficiency and pure technical efficiency of QISMUT banking market over the period of 2006 to 2016. The remaining of this paper consists of sections dealing with the empirical studies of intellectual capital as presented in Past Studies section follows by Data and Methodology section. The subsequent section presents the results and the discussion of the results while the Conclusion sections offers summary of the results as well the policy implications.

\section{Past Studies}

Structure-Conduct-Performance paradigm developed by Mason (1939) is under structural approach with other measurements such as concentration ratio (CR), Herfindahl-Hirschman Index (HHI) and efficiency hypothesis. SCP paradigm gained more attention from the researchers including Bain (1951, 1956). In SCP, performance of the firms was influenced by conduct. Conduct in this context, refers to non-pricing competition. The structural approach mostly used by the researcher in order to analyse the concentration and market structure. Non-structural approach developed as the researchers found deficiencies in traditional structural approach. The measurements in nonstructural approach consists of Panzar-Rosse model and Lerner Index. In other words, non-structural approach is known as New Empirical Industrial Organisation (NEIO) which are extension from SCP paradigm. Under NEIO, conduct in SCP trigger the competition in industry. In order to measure the competitiveness environment, Lerner Index and Panzar-Rosse are used since CR and HHI from structural approach are not measuring the competition. In terms of performance, the efficiency of the firms can be evaluated. According to 'Quiet Life Hypothesis' by Hicks (1935), firms that has market power often neglects the activities of the management which cause the inefficiency in the banks. In contrast, Demsetz (1973) came out with 'efficient structure hypothesis'. The gist of the hypothesis is efficient banks would create high profits which reflects an extraordinary performance.

Mkrtchyan (2005) found that Armenian banking sector operate under monopolistic competition in year 2001 to 2003 by using Panzar-Rosse approach. Meanwhile, Bhatti and Hussain (2010) found there is positive relationship between concentration and profitability. However, it was found negative relationship between market share and profitability. The findings do not support ES hypothesis. In addition, Gajurel and Pradhan (2012) found that there is high competition in interestbased market. Hassan, Mohamad and Bader (2009) studied the efficiency in Middle East banks consists of Islamic and conventional. The findings show that there are no differences in overall efficiency score between conventional and Islamic banks. Ahmad, Noor and Sufian (2010) found that 
INTERNATIONAL JOURNAL OF ACADEMIC RESEARCH IN BUSINESS AND SOCIAL SCIENCES Vol. 9, No. 6, June, 2019, E-ISSN: 2222-6990 C 2019 HRMARS

Islamic banks' pure technical efficiency (PTE) are more efficient compare to scale efficiency (SE). It was found that PTE are affecting technical efficiency (TE). Kablan and Yousfi (2011) found the size of the bank insignificant meanwhile market power and profitability have negative impact on efficiency.

In addition, Ab-Rahim, Kadri and Ismail (2013) found Islamic banks especially local banks are inefficient compare to Islamic foreign banks in terms of allocative efficiency and PTE. Besides, the authors also found allocative efficiency is the main contributor of cost efficiency in Malaysian Islamic banks. In contrast, Sillah and Harrathi (2015) found conventional banks perform well in terms of their efficiency score during financial crisis in 2008 compare to Islamic banks by using Data Envelopment Analysis (DEA). In terms of nexus between competition and efficiency, Ningaye, Mathilde and Luc (2014) found competition affects profit efficiency positively than cost efficiency. Andries and Capraru (2014) used Granger causality to find the relationship between competition and efficiency, it was found that efficiency positively affects the competition. Ab-Rahim (2016) studied the competition and efficiency of commercial banks and it was found that the concentration in commercial banks and affect positively on efficiency in terms of TE and PTE. The findings of Repkova and Stavarek (2013) shows efficiency and competition are positive relationship which also supported 'Quiet Life Hypothesis'. Apergis and Polemis (2016) found the banking industry of MENA is monopolistic and efficiency causes market share and concentration which result the profitability of the banks.

\section{Methodology}

In order to measure the concentration of the banking sector, Concentration Ratio and HerfindahlHirschman Index ( $\mathrm{HHI}$ ) are been used. Next, the measurement to examine the efficiency score of pure technical efficiency (PTE), technical efficiency (TE) and scale efficiency (SE) by using Data Envelopment Analysis (DEA). The period of the study involved are from year 2006 to 2016 and the data is extracted from Orbis Backscope. The dataset consists of 60 conventional and 32 Islamic banks in QISMUT banking market. The inputs and output variables employed in this study are adopted from the previous studies by De Guevara, Maudos and Perez (2005), Weill (2004) and Hamza and Kachtouli (2014) which is based on intermediation approach.

\section{Concentration Ratio (CR)}

$\frac{\text { Total Asset of two firm or bank }}{\text { Total Asset of all firms in the same industry }}$

Herfindahl-Hirschman Index (HHI)

$$
H H I=s 1^{2}+s 2^{2}+s 3^{2}+s 4^{2} \ldots s N^{2}
$$

$\mathrm{S}=$ Market share

$\mathrm{SN}=$ Number of the $\mathrm{xth}$ firms 
INTERNATIONAL JOURNAL OF ACADEMIC RESEARCH IN BUSINESS AND SOCIAL SCIENCES

Vol. 9, No. 6, June, 2019, E-ISSN: 2222-6990 @ 2019 HRMARS

\section{Efficiency}

In efficiency measurement, inputs and outputs variables are includes. Intermediation approach are used for Data Envelopment Analysis (DEA). Efficiency score is the maximum ratio of outputs to inputs (Ab-Rahim, Kadri \& Ismail, 2013). Variables involved as input and output are similar to the previous studies such as in Apergis and Polemis (2016), Giustiniani and Ross (2015), Castellanos and GarzaGarcia (2013), Ab-Rahim (2015), Abdul-Majid and Hassan (2011) and Abdul-Majid, Saal and Battisti (2010). The variables for inputs are deposits including short-term funding and personnel expenses whereas variables for outputs are total loans and other earnings assets.

$x i=$ virtual inputs $($ single $)$

$$
\begin{aligned}
& \operatorname{Max} u, v\left(\frac{u^{\prime} y i}{y^{\prime} x i}\right), \\
& \text { Subject to } \frac{u^{\prime} v j}{v^{\prime} x j} \leq 1 \\
& u, v \geq 0 j=1,2, \ldots N
\end{aligned}
$$

yi $=$ virtual outputs (single)

Decision-Making Units (DMU) will be evaluated from amount of different inputs (K) will produce different of outputs (M). DEA and DMU measure the efficiency in terms of overall technical efficiency. $\mathrm{xi}$ and $\mathrm{yi}$ are the $\mathrm{K}$ times $\mathrm{N}$ input matrix and $\mathrm{K}$ times $\mathrm{M}$ output matrix for $i$ th DMU. $\mathrm{X}$ which is $\mathrm{K}$ times $\mathrm{N}$ and $\mathrm{Y}$ is $\mathrm{K}$ times $\mathrm{M}$ for all data, $\mathrm{N}$ of DMUs. Finding the value of $\mathrm{u}$ and $\mathrm{v}$ are to prevent the problem of the infinite number if the efficiency of ith DMU is maximized.

Constant constraint (pxi = 1).

$$
\begin{gathered}
\operatorname{Max} u, v\left(u^{\prime} y i\right), \\
\operatorname{s.t} p x i=1 \\
u y j-p^{\prime} x j \leq 0 \\
j=1,2, \ldots N \\
u, p \geq 0
\end{gathered}
$$

$u$ and $p$ are from the transformation value of $u$ and $v$. Linear programming difficulties from the envelopment are shown as below:

$$
\begin{gathered}
\operatorname{Min} \theta, \lambda \theta \\
\text { s.t. }-y i+Y \lambda \geq 0, \\
\theta x i-X \lambda \geq 0 \\
j=1,2, \ldots N
\end{gathered}
$$

$\theta$ is a scalar while $\lambda$ are $\mathrm{N}$ times 1 which is vector of constants. The efficiency of the score in ith DMU represent by the value of $\theta$ and this can be solved by $N$.

$\operatorname{Min} \theta, \lambda \theta$

$$
\begin{gathered}
\text { s.t. }-y i+Y \lambda \geq 0 \\
\theta i-X \lambda \geq 0,
\end{gathered}
$$


INTERNATIONAL JOURNAL OF ACADEMIC RESEARCH IN BUSINESS AND SOCIAL SCIENCES Vol. 9, No. 6, June, 2019, E-ISSN: 2222-6990 (C) 2019 HRMARS

$$
\begin{aligned}
& N 1^{\prime} \lambda=1 \\
\lambda \geq 0, &
\end{aligned}
$$

$\mathrm{N} 1$ is an $\mathrm{N}$ time 1. Technical efficiency (TE) scores are from CRS model and pure technical efficiency (PTE) scores are from a variable return to scale (VRS). Scale efficiency (SE) are from CRS to VRS.

Discussion of the Results

Table 1: Market Structure of QISMUT Banking Market (2006 - 2016)

\begin{tabular}{lllllll}
\hline \multirow{2}{*}{ Country } & \multicolumn{2}{l}{ Total Assets } & \multicolumn{2}{l}{ Total Loans } & \multicolumn{2}{l}{ Total Deposits } \\
\cline { 2 - 7 } & $\mathrm{CB}$ & $\mathrm{IB}$ & $\mathrm{CB}$ & $\mathrm{IB}$ & $\mathrm{CB}$ & $\mathrm{IB}$ \\
\hline Qatar & 0.87 & 0.76 & 0.87 & 0.80 & 0.87 & 0.79 \\
Indonesia & 0.73 & 0.89 & 0.70 & 0.89 & 0.74 & 0.88 \\
Saudi Arabia & 0.48 & 0.84 & 0.45 & 0.86 & 0.47 & 0.90 \\
Malaysia & 0.45 & 0.41 & 0.47 & 0.51 & 0.44 & 0.42 \\
United Arab Emirates & & & & & & \\
(UAE) & 0.46 & 0.72 & 0.45 & 0.72 & 0.48 & 0.73 \\
Turkey & 0.71 & 0.73 & 0.70 & 0.73 & 0.70 & 0.72 \\
Mean & 0.58 & 0.73 & 0.58 & 0.75 & 0.58 & 0.74 \\
\hline
\end{tabular}

Note: $\mathrm{CB}$ is conventional banking sector and IB is Islamic banking sector

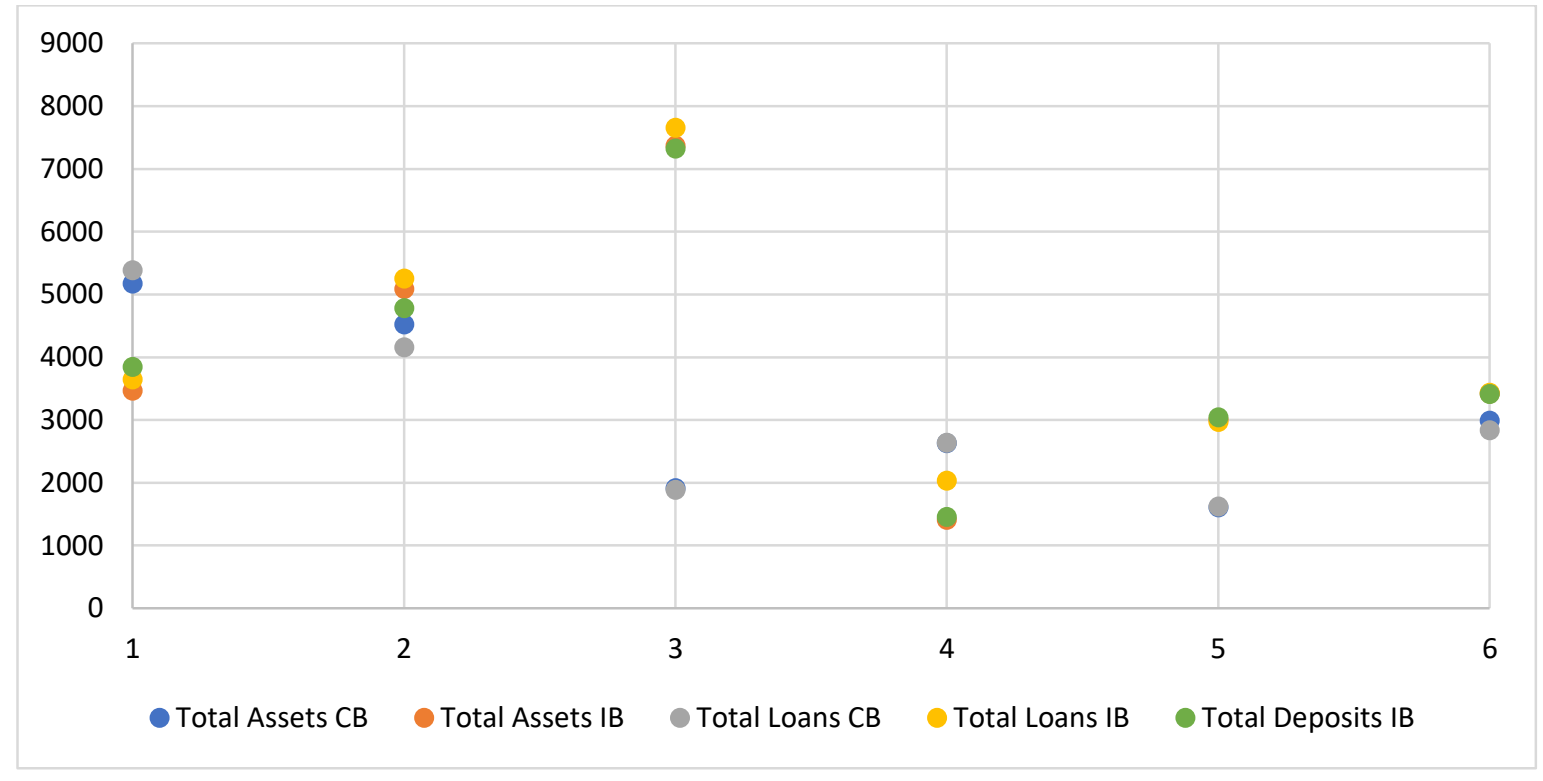

Figure 1: HERFINDAHL-HIRSCHMAN INDEX (HHI) OF BANKING SECTOR

Note: $C B$ is conventional banking sector and IB is Islamic banking sector, $1=$ Qatar, $2=$ Indonesia, 3=Saudi Arabia, 4= Malaysia, 5= UAE, 6= Turkey 
INTERNATIONAL JOURNAL OF ACADEMIC RESEARCH IN BUSINESS AND SOCIAL SCIENCES Vol. 9, No. 6, June, 2019, E-ISSN: 2222-6990 @ 2019 HRMARS

Based on Table 1, in terms of total assets, the mean shows that Islamic banks (0.73) are more concentrated compare to conventional (0.58) banking sectors. This reflects that the size of the banks in QISMUT are dominated by Islamic banks as shown in concentration ratio. The lowest concentration ratio in total assets are scored by Malaysia for its conventional and Islamic banking sector. This indicates that Malaysian banking sector high competition compare to Qatar (0.87) and Indonesia (0.89) for conventional and Islamic banking sector respectively.

Next, for total loans, once again Islamic (0.75) banks recorded as concentrated in market of loans in QISMUT according to their mean. It shows that the competition level for market of loans are less competitive because of the preferences or the majority of Muslim in these countries. Besides, it indicates that conventional banking sector in QISMUT are competitive to attract customers which only recorded 0.58. Saudi Arabia score 0.45 in total loans which means that conventional banking sector are quite competitive compare to Qatar (0.87). For Islamic banking sector, Malaysia once again found to be competitive with score of 0.51 compare to Indonesia, 0.89 .

Similar to market of deposits, conventional concentration ratio, 0.58 which is quite high competition compare to Islamic banking sector. Among QISMUT countries, Malaysia are experience in high competition with score of 0.44 and 0.42 for conventional and Islamic banking sector respectively. As for Figure 1, the trend is similar with the concentration ratio of QISMUT in total assets, total loans and deposits. It indicates that $\mathrm{HHI}$ of Islamic banks are higher than conventional. This reflects that QISMUT Islamic banking sector are less competitive than its conventional banking sector.

\section{Efficiency}

Table 2: Efficiency Performance of QISMUT Banking Market (2006-2016)

\begin{tabular}{|c|c|c|c|c|c|c|}
\hline \multirow[b]{2}{*}{ Year } & \multicolumn{2}{|c|}{$\begin{array}{l}\text { Pure Technical } \\
\text { Efficiency (PTE) }\end{array}$} & \multicolumn{2}{|c|}{$\begin{array}{l}\text { Technical Efficiency } \\
\text { (TE) }\end{array}$} & \multicolumn{2}{|c|}{$\begin{array}{l}\text { Scale Efficiency } \\
\text { (SE) }\end{array}$} \\
\hline & CB & IB & CB & IB & CB & IB \\
\hline Qatar & 75.24 & 88.91 & 74.63 & 85.45 & 95.63 & 95.86 \\
\hline Indonesia & 65.18 & 89.39 & 56.41 & 74.17 & 87.64 & 83.29 \\
\hline Saudi Arabia & 95.44 & 100.00 & 93.07 & 95.54 & 97.57 & 95.54 \\
\hline Malaysia & 75.75 & 80.34 & 52.16 & 74.71 & 69.49 & 92.80 \\
\hline UAE & 80.62 & 90.20 & 74.31 & 86.63 & 92.62 & 95.53 \\
\hline Turkey & 59.75 & 92.11 & 50.24 & 85.58 & 86.94 & 92.98 \\
\hline Mean & 75.33 & 90.16 & 66.80 & 83.70 & 88.31 & 92.69 \\
\hline
\end{tabular}

Table 2 shows the efficiency score of QISMUT conventional and Islamic banking sector. In terms of PTE, it shows that Islamic banking sector are more efficient compare to conventional. This means that Islamic banks has succeed to utilize their inputs to produce their outputs. In order to compare countries, it was found that Saudi Arabia are the most efficient in its Islamic banking sector which score 100 among other QISMUT countries. Interestingly, in conventional banking sector, once again Saudi Arabia are found to be efficient. In contrast, from Table 3, Turkey score the lowest efficiency score which is 59.75 for conventional banking sector whilst Malaysia score 80.34 in Islamic banking 
INTERNATIONAL JOURNAL OF ACADEMIC RESEARCH IN BUSINESS AND SOCIAL SCIENCES

Vol. 9, No. 6, June, 2019, E-ISSN: 2222-6990 C 2019 HRMARS

sector. From the efficiency score of both countries, it indicates that Turkey and Malaysia are not utilizing their inputs.

In terms of TE, once again Saudi Arabia score the highest efficiency score which are 93.07 and 95.54 for conventional and Islamic respectively. Turkey score the lowest efficiency score with 50.24 for conventional banking sector meanwhile in Islamic banking sector, Indonesia score 74.17 which are the lowest among QISMUT. Saudi Arabia shows that they are only 6.93 per cent and 4.46 per cent of inputs to be wasted for conventional and Islamic in order to produce outputs. In contrast, for Turkey wasted their inputs by 49.76 in conventional banking sector meanwhile for Indonesia, it was 25.83 per cent.

SE shows that whether the banking sector operate under optimal production. In conventional banking sector, it was found that Saudi Arabia score 97.57 which is the highest SE followed by Qatar (95.63). In Islamic banking sector, it was Qatar score 95.86 followed by Saudi Arabia, 95.54. Among QISMUT, from the results in Table 3, Malaysia score the lowest SE with 69.49 in conventional meanwhile Indonesia score 83.29 in Islamic banking sector. Overall, in terms of mean, it indicates that Islamic banking sector in QISMUT are found to be efficient compare to conventional banking sector.

\section{Conclusion}

The results of this study show QISMUT Islamic banks are more concentrated as compare to conventional banks; which could be explained by the dominance of Islamic banks in the context of QISMUT banking market. The findings also indicate QISMUT Islamic banks are more efficient than the conventional banks. This finding was supported by Abdul-Rahman and Rosman (2013) which found that Islamic banks in QISMUT are found to be efficient. The results imply Islamic banks are more efficient in managing their inputs. In addition, the findings show the changes of market structure in QISMUT banking market is due to increasing the demand of Islamic finance and services.

Since QISMUT are the major players in Islamic banking sector, it is interesting to study and compare their market structure and efficiency for both sectors. Unique concept of Islamic banking attracts the customers in QISMUT despite their population are Muslim majority. The main findings indicate Islamic banking are more concentrated compare to conventional banking sector. The policymakers should create the guidelines in order both banking sectors become efficient. These implemented guidelines will encourage banks to minimize the costs and reduce the wastage of their inputs in order to produce outputs.

Acknowledgement: This work was supported by Ministry of Education, Malaysia and Universiti Malaysia Sarawak [grant numbers F01/FRGS/1607/2017]. 
INTERNATIONAL JOURNAL OF ACADEMIC RESEARCH IN BUSINESS AND SOCIAL SCIENCES

Vol. 9, No. 6, June, 2019, E-ISSN: 2222-6990 @ 2019 HRMARS

\section{References}

Ab-Rahim, R., Kadri, N., \& Ismail, F. (2013). Efficiency performance of Malaysian Islamic banks. Munich Personal RePEc Archive, 1-10.

Ab-Rahim, R. (2015). Ranking of Malaysian commercial banks: Super-efficiency data envelopment analysis (DEA) approach. Asian Academy of Management Journal of Accounting \& Finance, 11(1), 124-143.

Ab-Rahim, R. (2016). Does competition foster efficiency? Empirical evidence from Malaysian commercial banks. Asian Academy of Management Journal of Accounting and Finance, 12(1), 2-23.

Abdul-Majid, M., Saal, D. S., \& Battisti, G. (2010). Efficiency in Islamic and conventional banking: An international comparison. Journal of Productivity Analysis, 34(1), 25-43.

Abdul-Majid, M., \& Hassan, M. K. (2011). The impact of foreign-owned Islamic banks and Islamic bank subsidiaries on the efficiency and productivity change of Malaysian banks. Journal of King Abdulaziz University, Islamic Economics, 24(2), 149-176.

Abdul-Rahman, A. R., \& Rosman, R. (2013). Efficiency of Islamic banks: A comparative analysis of MENA and Asian countries. Journal of Economic Cooperation and Development, 34(1), 63-92.

Ahmad, N. H. B., Noor, M. A. N. M., \& Sufian, F. (2010). Measuring Islamic banks efficiency: The case of world Islamic banking sectors. Journal of Islamic Banking and Finance, 27(4), 1-24.

Andries, A. M., \& Căpraru, B. (2012). Competition and efficiency in EU27 banking system. Baltic Journal of Economics, 12(1), 41-60.

Apergis, N., \& Polemis, M. L. (2016). Competition and efficiency in the MENA banking region: A nonstructural DEA approach. Applied Economics, 48(54), 5276-5291.

Bain, J. (1951). Relation of profit rate to industry concentration. Quarterly Journal of Economics, 65, 293-324.

Bain, J. (1956). Barriers to New Competition. Cambridge: Harvard Press.

Bhatti, G. A., \& Hussain, H. (2010). Evidence on structure conduct performance hypothesis in Pakistani commercial banks. International Journal of Business and Management, 5(9), 174187.

Castellanos, S., \& Garza-Garcia, J. G. (2013). Competition and Efficiency in the Mexican Banking Sector (Working Paper 13/29). Mexico City: BBVA Bancomer.

Casu, B., \& Girardone, C. (2009). Competition issues in European banking. Journal of Financial Regulation and Compliance, 17(2), 119-133.

De Guevara, J. F., Maudos, J., \& Perez, F. (2005). Market power in European banking sectors. Journal of Financial Services Research, 27(2), 109-137.

Demirguc-Kunt, A., \& Detragiache, E. (1998). Financial liberalization and financial fragility (No.1917). International Monetary Fund.

Demirguc-Kunt, A., Levine, R., \& Min, H. G. (1998). Opening to foreign banks: Issues of stability, efficiency, and growth. The implications of globalization of world financial markets, 83-115.

Demsetz, H. (1973). Industry structure, market rivalry and public policy. Journal of Law and Economics, 16, 1-10.

Ernst \& Young (2016). The world Islamic banking competitiveness report 2015 - 2016. 
INTERNATIONAL JOURNAL OF ACADEMIC RESEARCH IN BUSINESS AND SOCIAL SCIENCES

Vol. 9, No. 6, June, 2019, E-ISSN: 2222-6990 (C) 2019 HRMARS

Gajurel, D. P., \& Pradhan, R. S. (2012). Concentration and competition in Nepalese banking. Journal of Business Economics and Finance, 1(1), 5-16.

Giustiniani, A., \& Ross, K. (2015). Bank competition and efficiency in the FYR Macedonia. South Eastern Europe Journal of Economics, 6(2), 146-167.

Hamza, H., \& Kachtouli, S. (2014). Competitive conditions and market power of Islamic and conventional commercial banks. Journal of Islamic Accounting and Business Research, 5(1), 29-46.

Hassan, T., Mohamad, S., \& Bader, M. K. I. (2009). Efficiency of conventional versus Islamic banks: Evidence from the Middle East. International Journal of Islamic and Middle Eastern Finance, 2(1), 46-65.

Hicks, J. (1935). The theory of monopoly. Econometrica, 3, 1-20.

Kablan, S., \& Yousfi, O. (2011). Efficiency of Islamic and conventional banks in countries with Islamic banking. Munich Personal RePec Archive.

Mason, E. (1939). Price and production policies of large-scale enterprise. The American Economic Review, 29(1), 61-74.

Mkrtchyan, A. (2005). The evolution of competition in banking in a transition economy: An application of the Panzar-Rosse model to Armenia. The European Journal of Comparative Economics, 2(1), 67-82.

Ningaye, P., Mathilde, M. Y., \& Luc, N. N. (2014). Competition and banking efficiency in the CEMAC zone. International Journal of Economics and Finance, 6(6), 1-27.

Rajan, R. G., \& Zingales, L. (2003). The great reversals: The politics of financial development in the twentieth century. Journal of financial economics, 69(1), 5-50.

Repkova, I., \& Stavarek, D. (2013). Relationship between competition and efficiency in the Czech banking industry. Acta Universitatis Agriculturae et Silviculturae Mendelianae Brunensis, 61(7), 2701-2707.

Sillah, B. M. S. \& Harrathi, N. (2015). Bank efficiency analysis: Islamic banks versus conventional banks in the Gulf Cooperation Council Countries 2006-2012. International Journal of Financial Research, 6(4), 143-150.

Schaeck, K. and Cihak, M., (2008). How does competition affect efficiency and soundness in banking? New empirical evidence (European Central Bank Working Paper 932). Frankfurt, Germany: European Central Bank.

Weill, L. (2004). On the relationship between competition and efficiency in the EU banking sectors. Kredit and Kapital, 329-352. 